\title{
Anna Górajek
}

Warszawa

\section{POD PRĄD OPINII. KIEDY NIEMOŻLIWE STAJE SIĘ MOŻLIWYM - OBCOKRAJOWCY W NIEMCZECH}

Cudzoziemcy napływają do Republiki Federalnej od z górą pięćdziesięciu lat, tj. od momentu podpisania pierwszych umów o rekrutacji pracowników z Włochami (1955), Hiszpanią (1960), Grecją (1960) czy Turcją (1961). Wbrew umowom wielu pracowników najemnych pozostaje w Niemczech na stałe i nie wyjeżdża stąd nawet po osiągnięciu wieku emerytalnego. Średnia długość pobytu w RFN obywateli Turcji, Włoch, Grecji, Chorwacji czy Serbii (czyli byłej Jugosławii) wynosi ponad 20 lat $^{1}$. Kraj dobrobytu, jakim są Niemcy, przyciąga jak magnes imigrantów z całego świata. Statystyki wykazują jednak, że od połowy lat 90. liczba obcokrajowców utrzymuje się w RFN na podobnym poziomie: 1995 - 7.342 .779 (9\% ogółu mieszkańców), 2011 - 7.369 .909 (9\%), w ostatnich dwóch latach wykazując lekką tendencję wzrostową ${ }^{2}$ Tę pozorną niespójność tłumaczą z jednej strony powroty imigrantów do krajów pochodzenia lub ich dalsza migracja, z drugiej proces naturalizacji, w wyniku którego rokrocznie kilkadziesiąt tysięcy obcokrajowców staje się Niemcami. Współcześnie większość przybywających do RFN cudzoziemców to mieszkańcy krajów UE, bowiem wraz z postępującą integracją osiedlenie się w Niemczech osób mających obce, ale europejskie obywatelstwo stało się o wiele prostsze. Obywatele UE korzystają bowiem z prawa do swobodnego przemieszczania się i osiedlania w dowolnym miejscu na terytorium Unii. Dla porównania: w 2011 roku z krajów UE przyjechało na pobyt czasowy bądź stały ponad 356.700 osób, a spoza UE 265.700 (w tym z Turcji - 21.058 osób) ${ }^{3}$.

${ }^{1}$ Statistisches Bundesamt Deutschland, III Ausländische Bevölkerung - Ausländer nach Aufenthaltsdauer, http://www.destatis.de (29 listopada 2012).

2 Statistisches Bundesamt Deutschland, III Ausländische Bevölkerung - Ausländische Bevölkerung im Zeitverlauf, http://www.destatis.de (29 listopada 2012).

${ }^{3}$ Statistisches Bundesamt Deutschland, II Zu- und Abwanderung, http://www.destatis. de (29 listopada 2012). 
W 2011 roku najwięcej obcokrajowców przybyło z Polski (106.003), Rumunii (64.668) i Bułgarii (34.507). Charakterystycznym jest, że w Niemczech osiedlają się w ostatnich latach głównie mieszkańcy nowych krajów członkowskich UE oraz państw pogrążonych w kryzysie gospodarczym - jak Włochy, Grecja, Hiszpania czy Portugalia. Niemniej nadal największą grupę wśród obcokrajowców stanowią Turcy $(1.607 .161=23 \%$ ogółu obcokrajowców). Drugą pod względem liczebności grupę tworzą obywatele Włoch $(520.159=7,5 \%)$, a trzecią Polacy $(468.481=6,8)^{4}$. Summa summarum $10 \%$ ludności zamieszkującej między Renem a Odrą stanowią obcokrajowcy, co dla rządu federalnego, ale i dla społeczeństwa niemieckiego stanowi niewattpliwie pewne wyzwanie. Bowiem imigranci, to obcy kulturowo element, posługujący się innym językiem, mający inne zwyczaje i standardy zachowań, często wyznający inną religię. Czy możliwe jest współistnienie różnych kultur w ramach jednego państwa? Każda odpowiedź znajdzie we współczesnym świecie swoje potwierdzenie. W Niemczech od kilku lat słychać narzekania, że rodzima polityka ukierunkowana na integrację cudzoziemców poniosła klęskę. Czy rzeczywiście? Czy nie przeczy temu chociażby fakt, że co roku kilkadziesiąt tysięcy cudzoziemców otrzymuje niemieckie obywatelstwo? I czy tak uogólniona krytyka jest uzasadniona, jeśli uświadomimy sobie, że mówiąc o kłopotach integracyjnych media w Niemczech mają na myśli głównie imigrantów z Turcji, czasem późnych przesiedleńców z byłego ZSRR, ale krytyka ta nie dotyczy całej rzeszy innych imigrantów, procentowo rzecz ujmując większości z nich?

W niniejszym artykule chciałabym zwrócić uwagę na dwa obszary, które pozwalają spojrzeć na problem integracji z pewnym optymizmem. Pierwszym, który często niesłusznie bywa trywializowany, jest sport. Drugim zaś jest udział obywateli RFN obcego pochodzenia w reprezentacji politycznej społeczeństwa niemieckiego. Zarówno w sporcie, jak i w polityce ludzie ci są nie tylko akceptowani, ale stanowią niejako naturalną cząstkę Niemiec. Nie oznacza to oczywiście, że problem integracji imigrantów nie istnieje, ale jak to często bywa, nagłaśniane są przede wszystkim przykłady negatywne, gdyż stanowią one doskonałą pożywkę dla mediów. Niemniej istnieje również wiele przykładów udanej integracji obcokrajowców. Rzadko kiedy mają one jednak istotną wartość medialną, co oznacza, że pozostają w cieniu innych komunikatów lub giną w ogól-

${ }^{4}$ Statistisches Bundesamt Deutschland, III Ausländische Bevölkerung - Ausländer nach Staatsangehörigkeit, http://www.destatis.de (29 listopada 2012).W tej statystyce nie uwzględnia się osób posiadajacych podwójne obywatelstwo. Nieco inaczej przedstawia się sytuacja w przypadku obywateli niemieckich obcego pochodzenia. Tu najliczniejszą grupę stanowią co prawda również Turcy, stanowiąc 15,8\% ogółu obywateli z tłem migracyjnym, ale drugą pod względem liczebności grupę stanowią Polacy $(8,3 \%)$, kolejne zaś Rosjanie (6,7\%), Włosi (4,7\%) i Kazachowie (4,6\%). 
nym szumie informacyjnym. Udana integracja nie wzbudza bowiem tak silnych emocji, chyba że decyduje o zwycięstwie drużyny narodowej.

Jeśli przyjrzymy się niemieckiej męskiej drużynie narodowej w piłce nożnej to zauważymy, że wśród 23 zawodników uczestniczących w rozgrywkach EURO 20127 miało tzw. tło migracyjne (ponad 30\% składu reprezentacji). Określenie to odnosi się do ludności napływowej, która po 1949 roku przybyła na terytorium dzisiejszej Republiki Federalnej, jak również do wszystkich obcokrajowców urodzonych w Niemczech oraz do Niemców urodzonych w Niemczech, których przynajmniej jedno z rodziców przybyło po 1949 roku do Niemiec lub urodziło się tu jako obcokrajowiec. W omawianym przypadku dotyczy to zarówno Podolskiego i Klosego, przybyłych do RFN z Polski jako tzw. późni przesiedleńcy, jak również urodzonych w Niemczech Özila i Gündogana, Niemców tureckiego pochodzenia, a także Khediry, którego matka jest Niemką a ojciec Tunezyjczykiem, Gomeza - matka Niemka, ojciec Hiszpan oraz Boatenga - matka Niemka, ojciec z Ghany. Powołanie tych zawodników do drużyny narodowej Niemiec najlepiej świadczy o tym, że integracja jest nie tylko możliwa, ale że stała się faktem. Zawodnicy ci reprezentują Niemcy, są Niemcami, chociaż nie odcinają się ani od korzeni, ani od kultury kraju pochodzenia swojego lub swoich rodziców. „Na boisku pochodzenie nie jest ważne. Nie ma znaczenia, czy jesteś z Polski, Turcji, czy z Afryki” - twierdzi Łukasz Podolski i zaznacza, że Niemcy "od lat tworzą fajny zespół”5.

Podolski podkreśla w udzielanych zarówno polskim, jak i niemieckim mediom wywiadach, że Polska jest dla niego ważna, że jego żona jest Polką i że w Polsce mieszka część jego rodziny. Piłkarz często powtarza, że ma polskie serce, bo urodził się w Gliwicach. Ale czuje się też Niemcem, bo wychował się i prawie całe życie spędził właśnie w tym kraju ${ }^{6}$. Jak wielu spośród późnych przesiedleńców z Polski ma dwa obywatelstwa - polskie i niemieckie. Od momentu, kiedy Polska stała się członkiem UE jest to jak najbardziej legalne. Gra w koszulce z czarnym orłem na piersi, co tylko momentami piłkarzowi trochę doskwiera, mianowicie wtedy, gdy gra przeciwko Polsce. Tak było dla przykładu w Klagenfurcie w 2008 roku, kiedy w fazie grupowej mistrzostw Europy w Austrii Polska przegrała z Niemcami 0:2. Obydwie bramki strzelił Podolski z podań Klosego. I wyjątkowo nie okazywał radości. Wspominając te chwile mówił: „Na boisku zrobiłem swoje, musiałem. Ale naprawdę z dużym bólem serca. Czułem się trochę tak, jakbym strzelał swoim" ${ }^{\prime 7}$. Jednak na koniec EURO Podolski cieszył się wraz ze swoją drużyną i z niemieckimi fanami ze zdobycia wicemistrzostwa. Thomas Urban zjawisko to określa mianem podwójnej tożsamości

\footnotetext{
5 P. Drażba, Polskie serce. Niemiecka krew, „Futbol” 2011, nr 6-7 (56), s. 115.

${ }^{6}$ Por. ibidem, s. 114.

${ }^{7}$ Ibidem.
} 
narodowej ${ }^{8}$. Podobnie ambiwalentne odczucia towarzyszą i innym zawodnikom. Grają dla Niemiec, bo tu się urodzili lub dorastali. Reprezentują nowe wielokulturowe Niemcy i Niemców, których ta wielokulturowa reprezentacja jednoczy jak nic innego. Z nią się utożsamiają, ona stanowi uznany i ceniony symbol narodowy.

Ulrich Hesse twierdzi, że w latach 90. niemieckie murawy zaroiły się od dzieci z niezwykle różnorodnymi drzewami genealogicznymi. To drugie, bądź trzecie pokolenie imigrantów-gastarbeiterów. Wśród nich był także Mesut Özil, który urodził się w Gelsenkirchen, w rodzinie imigrantów tureckich. Piłkarz reprezentacji Niemiec na boisku nigdy nie czuł się obco. Twierdzi, że zawsze grał w multikulturowych zespołach: „Byli tam Libańczycy, Polacy, Turcy i Niemcy. W drużynie czuliśmy się jak rodzina i wszyscy sobie pomagali"9. Wielokulturowość od lat jest normalnością w niemieckich drużynach na poziomie juniorów i amatorów. Było tylko kwestią czasu, by stała się normą na poziomie pierwszej reprezentacji, która - jak to określił największy piłkarski magazyn w Niemczech „11 Freunde" - przeszła przemianę z „ociężałych czołgów do multikulturowych piłkarskich estetów"10. Skład reprezentacji RFN na EURO 2012 nie stanowi wyjątku. Na Mistrzostwa Świata rozgrywane w Republice Federalnej w 2006 roku do kadry powołano 5 zawodników o niecałkowicie niemieckich korzeniach (21,7\%). Na dzień dzisiejszy wśród 30 zawodników $\mathrm{w}$ szerokiej kadrze jest 9 piłkarzy z $\mathrm{tzw}$. tłem migracyjnym ${ }^{11}$. Stanowią oni dokładnie 30\% składu. Trzydzieści procent to proporcjonalnie trzy razy więcej niż liczba obywateli Niemiec z tzw. tłem migracyjnym, których szacuje się na 8,6 miliona, co stanowi w przybliżeniu 10\% społeczeństwa. Lub o jedną trzecią więcej niż wszystkich mieszkańców o nazwijmy to nie czysto niemieckich korzeniach, których zamieszkuje w RFN ok. 15,7 mln, co stanowi 19,3\% ogółu mieszkańców.

Oczywiście nie można na przykładzie jakiejkolwiek reprezentacji, a już zwłaszcza w piłce nożnej, udowadniać tezy o rozwiązaniu wszystkich problemów związanych z integracją imigrantów w Niemczech, ale jest to niezbity dowód, że integracja postępuje, a polityka integracyjna rządu nie tylko nie poniosła klęski, lecz pomału przynosi owoce. Nie można oczekiwać, że społeczeństwo nie mające tradycji wielokulturowości, w ciągu kilku krótkich dziesięcioleci całkowicie zmieni swoje nastawienie wobec przybyszów z zewnątrz. Potrzeba na to czasu i środków, zarówno

${ }^{8}$ T. Urban, Schwarze Adler, weiße Adler. Deutsche und polnische Fußballer im Räderwerk der Politik, Göttingen 2011, s. 9.

9 U. Hesse, Dlaczego Niemcy wygraja Euro? Bo to nie sa Niemcy, „FourFourTwo" 2012, nr 7 (20), Dodatek Faworycki, s. 11.

${ }^{10}$ Ibidem.

${ }^{11}$ Fußball - Nationalmannschaft, http://www.spiegel.de/thema/nationalelf/FußballNationalmannschaft (28 grudnia 2012). 
ustawowych, jak i finansowych oraz chęci obydwu stron - przyjmującej i przybywającej. Rząd niemiecki od kilku lat tworzy z myślą o integracji imigrantów specjalne programy. Od 2005 roku integracja uznawana jest za jedno z kluczowych zadań rządu. W 2006 roku odbył się 1. szczyt integracyjny, w którym obok przedstawicieli rządu federalnego udział wzięli przedstawiciele landów, gmin, organizacji pozarządowych i imigranckich. Stworzono pierwszy narodowy plan integracyjny, przeciwdziałający wykluczeniu i dyskryminacji ${ }^{12}$. Szczególny nacisk położono na wspieranie kompetencji językowych imigrantów, na kształcenie i przysposobienie zawodowe dzieci i młodzieży. Widać już pierwsze efekty podjętych działań. W ostatnich latach wzrosła liczba dzieci imigrantów objęta opieką przedszkolną. W 2010 roku już 85,7\% dzieci imigrantów w wieku od 3 do 6 lat uczęszczało do przedszkoli, gdzie szczególnie intensywnie uczą się języka niemieckiego ${ }^{13}$. Stopniowo zwiększa się też w tej grupie odsetek uczniów zdobywających wykształcenie średnie lub wyższe. W okresie od 2005 do 2010 roku odsetek uczniów-obcokrajowców, którzy uzyskali świadectwo dojrzałości wzrósł o $36 \%{ }^{14}$. W tym samym okresie odsetek tych, którzy nie ukończyli żadnej szkoły zmalał o 15\%, ale to oznacza, że nadal prawie 11.000 uczniów-obcokrajowców nie ukończyło nawet szkoły podstawowej ${ }^{15}$. Brak wykształcenia to obok braku znajomości języka niemieckiego jedna z głównych przyczyn utrzymującego się wciąż na dość wysokim poziomie bezrobocia wśród imigrantów. Ale i tu zaobserwowano pozytywną tendencję. W ciągu ostatnich pięciu lat bezrobocie wśród ludności napływowej spadło z 18\% do niespełna 12\%. Niestety odsetek bezrobotnych wśród imigrantów jest nadal prawie dwukrotnie wyższy niż wśród rdzennie niemieckiej ludności $(2010-6,1 \%)^{16}$.

To tylko kilka przykładów z rządowych statystyk, które napawają optymizmem, ale jednocześnie potwierdzają, że choć odnotowano pewną poprawę we wspomnianych dziedzinach, to brak wykształcenia, brak znajomości języka niemieckiego i bezrobocie stanowią nadal istotny problem, utrudniający rzeczywistą integrację cudzoziemców czy późnych przesiedleńców. W związku z tym pod koniec stycznia 2012 roku na 5. szczycie integracyjnym uzgodniono szczegóły tzw. narodowego planu ak-

${ }^{12}$ Por. Nationaler Intergrationsplan, http://www.bundesregierung.de/Content/DE/ StatischeSeiten/Breg/IB/2006.10.27.ib-nationaler-integrationsplan.html (28 grudnia 2012).

${ }^{13}$ Por. Die Beauftragte der Bundesregierung für Migration, Flüchtlinge und Integration, Kurz-Zusammenfassung mit ausgewählten Daten und Aussagen des 9. Berichts über die Lage der Ausländerinnen und Ausländer in Deutschland, s. 8, http://www.bundesregierung.de/Content/DE/_Anlagen/IB/2012-06-27-neunter-lagebericht-kurzfassung.pdf (14 grudnia 2012).

${ }^{14}$ Ibidem, s. 9.

15 Por. Die Beauftragte der Bundesregierung für Migration, Flüchtlinge und Integration, Integration in Deutschland, Eine Kurzdarstellung, s. 2, http://www.bundesregierung.de/ Content/DE/_Anlagen/IB/2012-09-18-dossier-integration.pdf (14 grudnia 2012).

${ }^{16}$ Por. Die Beauftragte..., Kurz-Zusammenfassung..., op. cit., s. 11. 
cyjnego integracja ${ }^{17}$. Przewiduje on kontynuację prac w zakresie kształcenia oraz rozszerzenie działań prointegracyjnych na inne dziedziny, takie jak sport, media czy kultura. Zwrócono też uwagę na konieczność zwiększenia udziału osób z tzw. tłem migracyjnym na wszystkich szczeblach administracji publicznej. W ostatniej z wymienionych dziedzin jest być może najwięcej do zrobienia.

Nie wszystko jednak można uregulować ustawą. Nie można np. zadekretować udziału imigrantów w życiu politycznym i społecznym. A jest to bez wątpienia probierz zarówno postawy propaństwowej imigrantów, jak i tolerancji społeczeństwa przyjmującego wobec nowych przybyszów. Warto się zatem przyjrzeć prezydiom i zarządom głównych partii politycznych, eurodeputowanym, deputowanym do Bundestagu czy parlamentów krajowych, składom rad gmin czy miast i odpowiedzieć na pytanie, czy obywatele Niemiec mający nieniemieckie korzenie uczestniczą aktywnie w życiu politycznym i społecznym Republiki Federalnej, czy współkształtują społeczeństwo, którego istotną cząstkę stanowią? Wnikliwa analiza danych pozwala na udzielenie odpowiedzi twierdzącej, chociaż jak to zwykle ze statystykami bywa, można wysnuć i odmienny wniosek.

Wśród sześciu partii reprezentowanych w Bundestagu dwóm przewodzą osoby ze wspomnianym już tłem migracyjnym - Philipp Rösler, urodzony w Wietnamie, wychowany w Niemczech w rodzinie adopcyjnej, jest przewodniczącym partii liberalnej FDP i pełni jednocześnie funkcję wicekanclerza w rządzie Angeli Merkel; Cem Özdemir, współprzewodniczy partii Bündnis 90/Die Grünen. Urodził się co prawda w Niemczech, lecz jego rodzice pochodzą z Turcji. Dwóch przywódców istotnych partii politycznych, to dużo czy mało?

Na 622 deputowanych do Bundestagu obecnej kadencji dwadzieścioro ma własne (9) bądź rodzinne (11) doświadczenie migracyjne - 5 ma korzenie tureckie, 4 irańskie, 3 indyjskie ${ }^{18}$. Pozostali belgijskie, chorwackie, czeskie, hiszpańskie, a także ukraińskie. Dwoje urodziło się w Polsce. To raptem 3,2\% wszystkich parlamentarzystów. Dużo czy mało? Mało, jeśli dane te odniesiemy do 10\% społeczeństwa Republiki Federalnej, które ma podobne co oni tło migracyjne. Jeszcze mniej, jeśli dodatkowo uwzględnimy kolejne $10 \%$ obcokrajowców na stałe mieszkających w Niemczech. Dużo, jeśli weźmiemy pod uwagę, że w Bundestagu poprzedniej kadencji

17 Por. Nationaler Aktionsplan Integration, http://www.bundesregierung.de/ Content/DE/_Anlagen/2011-12-14-aktionsplan-integration.pdf?_blob=publicationFile (30 listopada 2012).

1820 Bundestagsabgeordnete mit Migrationshintergrund, „Migazin. Migration in Germany" 29.09.2009, http://www.migazin.de/2009/09/29/20-bundestagsabgeordnete-mit-migrationshintergrund/all/1/(10 grudnia 2012); por. też http://www.bundestag.de (10 grudnia 2012). 
takich deputowanych było jedynie jedenaścioro, a po raz pierwszy przedstawiciele powojennej imigracji zasiedli w ławach parlamentu federalnego dopiero w roku 1994 - byli to Leyla Onur (SPD) i wspomniany powyżej Cem Özdemir (Zieloni). Trzeba sobie zatem uświadomić, że w ciągu niespełna dwudziestu lat liczba deputowanych, którzy przybyli do RFN jako obcokrajowcy lub których rodzice mieli inne niż niemieckie obywatelstwo, zwiększyła się dziesięciokrotnie lub jak kto woli wzrosła o 900\%.

Podobnie sytuacja wygląda na poziomie parlamentów krajowych. $\mathrm{Na}$ 1825 członków wszystkich parlamentów krajowych w 2010 roku było tylko 46 deputowanych, w których żyłach płynie nieniemiecka krew ${ }^{19}$. To niewiele. Ale jeśli uświadomimy sobie, że w roku 2000 było takich osób jedynie 12, to stwierdzimy, że w ciągu dziesięciu lat czterokrotnie wzrosła liczba członków parlamentów krajowych wywodzących się z tej grupy osób. I nie są to bynajmniej jedynie deputowani $t z w$. ostatniego rzędu. Coraz częściej pełnią oni istotne funkcje zarówno w komisjach, jak i frakcjach parlamentarnych. Dotychczas nie byli reprezentowani w rządach krajowych, ale i to się zmienia. Przykładem niedawna nominacja dla Aygül Özkan. Niemieckiej prawniczce o tureckich korzeniach powierzono tekę ministra ds. socjalnych w rządzie Dolnej Saksonii.

Przeprowadzone w ostatnim czasie przez Instytut Maxa Plancka badania wykazały, że w 77 dużych (powyżej 100000 mieszkańców) niemieckich miastach na 4670 radnych 198 ma przynajmniej częściowo obce korzenie $^{20}$. To jedynie 4,2\%, a wiadomo, że imigranci osiedlają się głównie w dużych miastach, w niektórych stanowiąc ponad 20\% mieszkańców. Niemniej analiza składu rad miejskich z lat 2001-2011 wykazała znaczący wzrost zaangażowania tej grupy obywateli $(2001-116$; 2011 - 198) w sprawy własnego miasta. Co prawda nadal w 15 miastach w składzie rady nie ma ani jednego radnego $\mathrm{z}$ tłem migracyjnym, ale w 2001 roku takich miast było jeszcze $24^{21}$.

Podobne wyliczenia można by mnożyć. Różnorodne statystyki dostarczają doskonały materiał badawczy. Wszystkie analizy potwierdzają jednak istnienie pozytywnej tendencji w obszarze zaangażowania społeczno-politycznego obywateli Republiki Federalnej, których określa się mianem osób z tłem migracyjnym. Coraz więcej obcokrajowców, którzy uzyskali niemieckie obywatelstwo lub ich dzieci angażuje się w związkach zawodowych, ruchach pokojowych czy organizacjach obywatelskich. Co ciekawe badania

${ }^{19}$ Por. K. Schönwälder, Einwanderer in Räten und Parlamenten, „Das Parlament. Mit der Beilage Aus Politik und Zeitgeschichte” 2010, nr 46-47, http://www.bpb.de/apuz/32374/ einwanderer-in-rätenßundßparlamenten?p=4 (11 grudnia 2012).

${ }^{20}$ Por. B. Fenzel, Vielfalt im Stadtrat, http://www.mpg.de/4622985/F001_Fokus_018-023. pdf (11.12.2012).

${ }^{21}$ Ibidem. 
wykazują, że młodzi migranci, zwłaszcza urodzeni w Niemczech przedstawiciele drugiej generacji, stosunkowo częściej podejmują działalność na rzecz organizacji pożytku publicznego niż ich niemieccy rówieśnicy ${ }^{22}$. Pomału też naturalizowani Niemcy zasilają szeregi partii politycznych. Za najbardziej przyjazne migrantom uznać trzeba partię Zielonych i lewicującą Die Linke. $Z$ ich szeregów wywodzi się ponad połowa deputowanych z tłem migracyjnym, chociaż członkami tych partii w parlamentach krajowych jest obecnie zaledwie $18 \%$ wszystkich parlamentarzystów ${ }^{23}$. Zieloni byli też pierwszą partią, która wprowadziła imigrantów do parlamentu krajowego. Pierwszym deputowanym-imigrantem w historii Republiki Federalnej był Sevim Çelebi, który w 1987 roku zdobył mandat do Izby Deputowanych wówczas jeszcze Berlina Zachodniego. Z kolei najmniej licznie reprezentowani są imigranci w partiach chadeckich, ale na przekór wszystkiemu to właśnie z szeregów CDU wywodzi się pani minister Aygül Özkan, która podkreśla, że najważniejsze są wyznawane wartości, a nie wyznawana religia ${ }^{24}$. Interesującym zjawiskiem są powstające przed wyborami samorządowymi lokalne inicjatywy wyborcze, zrzeszające głównie imigrantów i głównie ich wysuwających jako kandydatów do rad gmin i miast. Być może jest to sygnał wysyłany przez to środowisko pod adresem dużych partii politycznych, by w większym stopniu uwzględniały kandydatów z tłem migracyjnym na swoich listach. Co prawda żądania wprowadzenia na listach wyborczych kwot migracyjnych, analogicznie do parytetów, wydają się kontrowersyjne, chociażby z tego powodu, że dzieliłyby Niemców na „lepszych i gorszych", „prawdziwych i farbowanych (naturalizowanych)", a także mogłyby powodować konflikty na tle narodowościowym wśród samych zainteresowanych, to coraz większa liczba wyborców z tłem migracyjnym (w 2009 roku liczbę ich szacowano na 5,6 $\mathrm{mln}^{25}$ ) wymusi w sposób naturalny zwiększenie liczby reprezentantów z doświadczeniem migracyjnym zarówno na szczeblu lokalnym, jak i federalnym.

$\mathrm{Z}$ analizy danych dotyczących niemieckich parlamentarzystów wynika po części zaskakująca konstatacja. Okazuje się bowiem, że wśród politycznie zaangażowanych imigrantów prym wiodą imigranci z Tur$\mathrm{cji}^{26}$. Na przekór wszystkim pomówieniom o niechętnym stosunku do integracji, to właśnie ta narodowość może być innym stawiana za wzór.

${ }^{22}$ Por. Die Beauftragte..., Kurz-Zusammenfassung..., op. cit., s. 14.

${ }^{23}$ Por. B. Fenzel, op. cit.

${ }^{24}$ Por. T. Langenbach, Vom Flüchtling zum Politiker, „Weser Kurier” 05.12.2012, http://www.weser-kurier.de/bremen/politik2_artikel,-Vom-Flüchtling-zum-Politiker-_ arid,390178.html (20 grudnia 2012).

${ }^{25}$ Por. Pressemitteilung des Bundeswahlleiters 11.09.2009, http://www.presseportal.de/ pm/74247/der_bundeswahlleiter (09 grudnia 2012).

${ }^{26}$ Por. B. Fenzel, Vielfalt im Stadtrat, op. cit. 
W Bundestagu stanowią oni najliczniejszą grupę posłów o nieniemieckich korzeniach ( 5 na $20=25 \%$, przy czym wśród uprawnionych do głosowania niemieckich obywateli z tłem migracyjnym było zaledwie $10 \%$ pochodzenia tureckiego). Jeszcze wyraźniej ich dominację widać $w$ parlamentach krajowych, gdzie w 2009 roku na 39 deputowanych aż 20 miało korzenie tureckie, co stanowiło $51 \%$ tej grupy posłów ${ }^{27}$. Interesującym zjawiskiem jest również liczna reprezentacja płci pięknej w tej grupie. Być może tak silne zaangażowanie obywateli niemieckich pochodzenia tureckiego, a także stosunkowo liczny udział kobiet wynika z przeżytego grupowo bądź indywidualnie uczucia dyskryminacji i związanej z tym silnej potrzeby akceptacji. Część osób dostrzega też zapewne w polityce szansę awansu społecznego.

Ale wybór takiego a nie innego kandydata bądź kandydatki na radnego lub parlamentarzystę nie zależy li tylko od ich dobrych chęci, ale w głównej mierze od tego, jak i na kogo zagłosują wyborcy. Wybór kandydatów o pochodzeniu innym niż niemieckie świadczy dobitnie o zmieniającym się nastawieniu rdzennych Niemców do ludności napływowej, o akceptacji współobywateli o odmiennym kolorze skóry, nietypowym wyznaniu i czasem obco brzmiącym akcencie. Stały, aczkolwiek powolny, wzrost liczby radnych i deputowanych o obco brzmiących nazwiskach jest najlepszym dowodem dokonującej się przemiany. Przedstawiciele różnych grup ludności napływowej coraz liczniej angażują się na rzecz społeczności lokalnych, które ze swojej strony to zaangażowanie doceniają, dając temu wyraz m.in. poprzez kartę do głosowania. Decyzję taką ułatwia jednoznacznie pozytywne nastawienie tej części imigrantów do podstawowych praw i wolności zagwarantowanych Ustawą Zasadniczą. Żądania imigrantów odnośnie do uszanowania ich odmienności kulturowej są akceptowane i uznawane przez większość obywateli Republiki Federalnej, o ile nie godzą one $\mathrm{w}$ prawa i wolności innych osób, i nie stoją $\mathrm{w}$ jawnej sprzeczności z prawem niemieckim. W społeczeństwie niemieckim, w tym także wśród obywateli z tłem migracyjnym nie ma zgody na relatywizm kulturowy, który podawałby w wątpliwość prawa człowieka ${ }^{28}$. Tolerancja, jakiej słusznie domagają się imigranci w stosunku do siebie, obowiązuje także ich samych, co oznacza - jak sformułował to Cem Özdemir - że „kto z własnej woli decyduje się osiąść w Niemczech, musi uszanować prawo innych do rozwoju własnej osobowości, niezależnie od tego czy chodzi o własną córkę, czy homoseksualnego sąsiada"29. Imigranci nie mogą powołując się na wolność wyznania łamać prawa obowiązującego

${ }^{27}$ Por. K. Schönwälder, op. cit.

${ }^{28}$ Por. M. Kamann, Grüne finden plötzlich harte Worte für Migranten, "Die Welt" 04.11.2010, http://www.welt.de/10714829 (12 grudnia 2012).

${ }^{29}$ Ibidem. 
w Niemczech, nie mogą też - jak podkreśla Rahim Schmidt, pochodzący z Iranu deputowany do parlamentu Nadrenii-Westfalii - żądać dla siebie przywilejów w związku z wyznawaną religiąa ${ }^{30}$. Schmidt podkreśla słuszność zasady rozdziału kościoła od państwa. Wtóruje mu Memet Kilic, pochodzący z Turcji deputowany do Bundestagu, i podkreśla, że ani Koran, ani Biblia, ani Tora nie mogą stanowić ani źródła, ani wykładni prawa ${ }^{31}$.

Społeczeństwo niemieckie już dziś nie jest jednorodne narodowościowo. Pomału staje się ono społeczeństwem wielokulturowym i proces ten będzie się stopniowo nasilał, tym bardziej, że - jak podają statystyki - w 2009 roku aż jedna trzecia wszystkich dzieci poniżej piątego roku życia $(34,6 \%)$ miała korzenie imigranckie ${ }^{32}$. Pamiętać jednak należy, że jest to proces długofalowy i błędem jest oczekiwanie szybkiego, a jednocześnie rzeczywistego zintegrowania się często kulturowo całkowicie odmiennie ukształtowanych jednostek i grup. Żeby integracja mogła postępować niezbędne jest określenie pewnego minimum wartości, tworzącego niepodważalny fundament, na którym może być budowana prawdziwa jedność, pomimo kulturowej różnorodności. Takim minimum jest w ocenie obywateli Republiki Federalnej kanon podstawowych wartości, na których opiera się demokracja. Podkreślają to zarówno rodowici, jak i naturalizowani Niemcy. W ocenie tych ostatnich integracja to prawo i obowiązek jednocześnie: prawo do korzystania z wolności i obowiązek respektowania podstawowych wartości.

\section{Zusammenfassung}

Die Frage, ob die Integrationspolitik der Bundesregierung gescheitert ist, wird meistens bejaht, aber sie lässt sich auch verneinen. Im Artikel wird der Versuch unternommen auf Bereiche hinzuweisen, in denen Personen mit Migrationshintergrund immer aktiver die Gegenwart der Bundesrepublik mitgestalten. Einerseits wird auf die Rolle des Sports bei der Integration von Migranten hingewiesen, andererseits wird der Frage nachgegangen, inwieweit dieser Teil der deutschen Gesellschaft politisch aktiv ist, so z. B. in welchem Maße Politiker mit nichtdeutschen Wurzeln die Bürger der Bundesrepublik in Parlamenten, Stadt- und Gemeinderäten repräsentieren.

${ }^{30}$ Dietmar Brück: Abgeordneter Rahim Schmidt sieht Islam im Land kritisch, w: „Rhein-Zeitung" 27.08.2012, http://www.rhein-zeitung.de/regionales_artikel,-Abgeordneter-Rahim-Schmidt-sieht-Islam-im-Land-kritisch-_arid,475073.html (12.12.2012).

31 Por. dpa: Abgeordneter verteilt Gratis-Grundgesetz auf Marktplatz, w: "Spiegel”-Online 16.05.2012, http://www.spiegel.de/politik/deutschland/gruenen-abgeordneter-verteilt-gratis-grundgesetz-auf-marktplatz-a-833565.html (20.12.2012).

32 Bundeszentrale für politische Bildung, Zahlen und Fakten. Die soziale Situation in Deutschland. Migration. Bevölkerung mit Migrationshintergrund I, http://www.bpb.de/wissen. 